\title{
Transformation of diffuse large $B$ cell lymphoma into dendritic sarcoma under CAR T cell therapy detected on ${ }^{18} \mathrm{~F}$-FDG PET/CT
}

\author{
Michael Winkelmann ${ }^{1} \cdot$ Kai Rejeski $^{2}$ - Marcus Unterrainer ${ }^{1} \cdot$ Christian Schmidt $^{2} \cdot$ Michael Ruzicka $^{2}$ - Jens Ricke ${ }^{1}$. \\ Martina Rudelius $^{3} \cdot$ Marion Subklewe $^{2} \cdot$ Wolfgang G. Kunz ${ }^{1}$ (D)
}

Received: 23 June 2020 / Accepted: 11 August 2020 / Published online: 19 August 2020

(C) The Author(s) 2020

Chimeric antigen receptor (CAR) T cell immunotherapy uses patient-derived tumor antigen-directed $\mathrm{T}$ cells for targeted elimination of cancer cells [1]. The most common form applies modified $\mathrm{T}$ cells expressing a CAR specific for the CD19 antigen to treat relapsed or refractory lymphoma [2] and leukemia [3].

We present a 60 -year-old female patient with refractory diffuse large B cell lymphoma (DLBCL) who underwent CAR T cell therapy. During treatment, all lesions decreased in size with a complete metabolic response (Deauville score 1) in ${ }^{18} \mathrm{~F}$-FDG PET/CT imaging obtained 3 months after CAR T cell infusion (A). At the same time, multiple newly enlarged and hypermetabolic cervical lymph nodes (SUVmax value $=31$ ) were detected in a previously unaffected location (B). These new lesions (red circles and arrows) showed a morphological dedifferentiation with a large central hypodensity compared with nodal DLBCL target lesions at baseline CT (blue circles and arrows). This was also reflected by differences in the radiomic features entropy and uniformity $(\mathrm{C})$. These circumstances triggered a repeat histological workup that determined the transformation of the DLBCL (D; high

This article is part of the Topical Collection on Image of the month

Wolfgang G. Kunz

wolfgang.kunz@med.uni-muenchen.de

Michael Winkelmann

michael.winkelmann@med.uni-muenchen.de

1 Department of Radiology, University Hospital, LMU Munich, Marchioninistr. 15, 81377 Munich, Germany

2 Department of Medicine III, University Hospital, LMU Munich, Munich, Germany

3 Department of Pathology, University Hospital, LMU Munich, Munich, Germany
CD20 expression) into a sarcoma of the dendritic cells (E; high S100 expression) without residual lymphomatous tissue. Based on high PD-L1 expression, checkpoint inhibition with pembrolizumab was initiated.

Rare cases of transformation into histiocytic and dendritic cell neoplasms have been reported in patients with follicular lymphoma and DLBCL [4, 5]. This case underlines the diagnostic potential in the interlesional comparison of morphologic and metabolic features to raise the suspicion of clonal dedifferentiation. Future studies that correlate radiomic features from imaging and pathologic features from biopsies may not only lead to diagnostic improvements but also a better understanding of tumor biology in patients undergoing CAR $\mathrm{T}$ cell therapy.

Funding Information Open Access funding provided by Projekt DEAL.

\section{Compliance with ethical standards}

Conflict of interest All authors declare that they have no conflict of interest.

Informed consent Written informed consent was obtained from the patient. The ethical committee of LMU Munich waives additional approval for case reports from clinical practice.

Open Access This article is licensed under a Creative Commons Attribution 4.0 International License, which permits use, sharing, adaptation, distribution and reproduction in any medium or format, as long as you give appropriate credit to the original author(s) and the source, provide a link to the Creative Commons licence, and indicate if changes were made. The images or other third party material in this article are included in the article's Creative Commons licence, unless indicated otherwise in a credit line to the material. If material is not included in the article's Creative Commons licence and your intended use is not permitted by statutory regulation or exceeds the permitted use, you will need to obtain permission directly from the copyright holder. To view a copy of this licence, visit http://creativecommons.org/licenses/by/4.0/. 


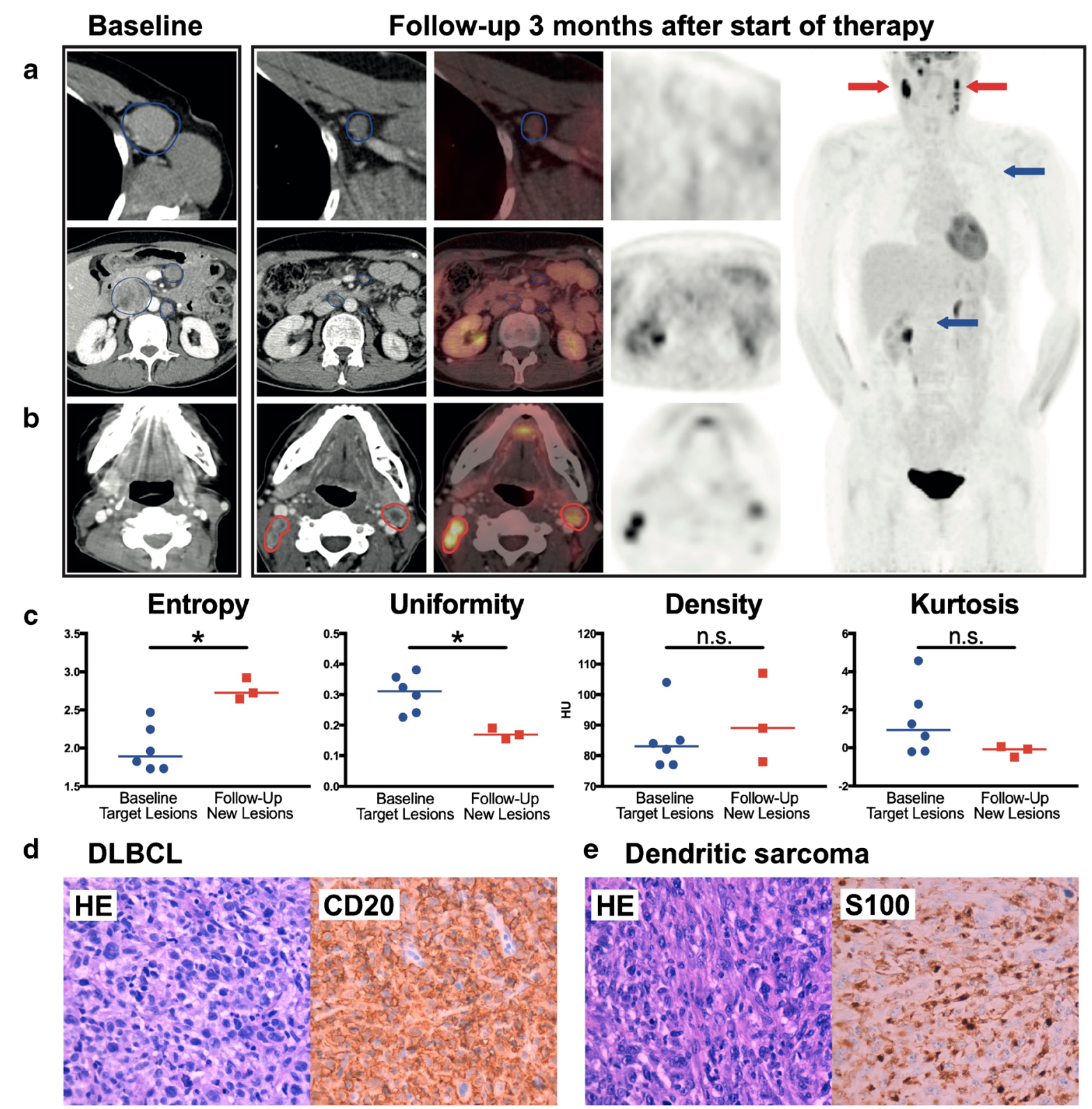

\section{References}

1. June CH, Sadelain M. Chimeric antigen receptor therapy. N Engl J Med. 2018;379:64-73. https://doi.org/10.1056/NEJMra1706169.

2. Neelapu SS, Locke FL, Bartlett NL, Lekakis LJ, Miklos DB, Jacobson CA, et al. Axicabtagene ciloleucel CAR T-cell therapy in refractory large B-cell lymphoma. N Engl J Med. 2017;377:253144. https://doi.org/10.1056/NEJMoa1707447.

3. Maude SL, Frey N, Shaw PA, Aplenc R, Barrett DM, Bunin NJ, et al. Chimeric antigen receptor $\mathrm{T}$ cells for sustained remissions in leukemia. N Engl J Med. 2014;371:1507-17. https://doi.org/10. 1056/NEJMoa1407222.

4. Feldman AL, Arber DA, Pittaluga S, Martinez A, Burke JS, Raffeld $\mathrm{M}$, et al. Clonally related follicular lymphomas and histiocytic/ dendritic cell sarcomas: evidence for transdifferentiation of the follicular lymphoma clone. Blood. 2008;111:5433-9. https://doi.org/ 10.1182/blood-2007-11-124792.

5. Ochi Y, Hiramoto N, Yoshizato T, Ono Y, Takeda J, Shiozawa Y, et al. Clonally related diffuse large B-cell lymphoma and interdigitating dendritic cell sarcoma sharing MYC translocation. Haematologica. 2018;103:e553-e6. https://doi.org/10.3324/ haematol.2018.193490.

Publisher's note Springer Nature remains neutral with regard to jurisdictional claims in published maps and institutional affiliations. 